\title{
MATHEMATICAL REPRESENTATION OF GRADE 7 STUDENTS IN SET THEORY TOPICS THROUGH PROBLEM-BASED LEARNING
}

\author{
Ida Lestari*1 ${ }^{1}$, Nila Kesumawati ${ }^{2}$, Yunika Lestaria Ningsih ${ }^{3}$ \\ ${ }^{1,2,3}$ Universitas PGRI Palembang
}

\section{Article Info}

Article history:

Received Nov 25, 2019

Revised Jan 29, 2020

Accepted Feb 6, 2020

Keywords:

Mathematical Representation, Problem-Based Learning, Set Theory

\begin{abstract}
Set theory has a wide role in mathematical concepts. Students have to understand the set theory before learning other concepts such as algebra and probability. This study aims to determine the effect of the problem-based learning (PBL) model on the students' mathematical representation in set theory topics. The method used in this study is a quasi-experiment design. The populations in this study were 289 students of 7 th grade at Secondary School in Palembang. The sample of this study were students of class 7.8 (control group) and 7.10 (experimental group). Data were collected through tests, interviews, and documentation. Based on data analysis, known that PBL affects the students' mathematical representation. Students who had the PBL model get the better score of mathematical representation. They could use the symbol of set correctly, represent the set into Venn diagram correctly and they also could explain their answer. Furthermore, the implementation of the PBL model is offered.
\end{abstract}

Copyright (c) 2020 IKIP Siliwangi. All rights reserved.

\section{Corresponding Author:}

Ida Lestari,

Departement of Mathematics Education,

Universitas PGRI Palembang

Jl. Jenderal A. Yani Lrg. Gotong Royong 9-10 Ulu, Palembang 30116, Indonesia.

Email: idalestariida21@gmail.com

\section{How to Cite:}

Lestari, I., Kesumawati, N., \& Ningsih, Y. L. (2020). Mathematical representation of grade 7 students in set theory topics through problem-based learning. Infinity, 9(1), 103-110.

\section{INTRODUCTION}

Set theory is an elementary concept that is crucial in mathematics. Learning mathematical concepts need knowing the set theory (Razmjooei, 2013). Additionally, Dogan-Dunlap (2006) said that it's the prerequisite concepts for algebra topics. "A set is defined in terms of certain properties shared by its elements. These properties must be well described, with no ambiguities, so that it is always clear whether a given element belongs to a given set or not" (Andre, 2014). But in fact, many students have to struggle in understanding this concept. Pinker (Zazkis \& Gunn, 1997) mentioned that they felt difficult in learning the concept of set.

Signs and symbols have a wide role in the concept of set. Bagni (2006) explained the representation of set, as follow : (1) Verbal: the definitions of set, element, subset, union, etc, (2) Symbolic: the set symbol (capital letter), the set operation symbols, the 
brackets, etc, and (3) Visual: the presenting of set in Venn diagram. These set representations are known as mathematical representations.

The mathematical representation is a capability that has to master by students in the learning of mathematics. It is based on one of the goals of mathematics learning by the National Council of Teacher Mathematics (NCTM). According to NCTM mathematical representation can be defined as the ability to restate the notation, symbols, tables, figures, charts, diagrams, equations or another mathematical expression into another form (Johar \& Lubis, 2018). It is associated with the student's understanding of mathematical concepts (Bolden, Barmby, Raine, \& Gardner, 2015). Students who have good mathematical representation will easier in understanding the mathematical concepts. However, despite the crucial mathematical representation as to the goal learning of mathematics, students still lack this capability. Previous studies said that many students still have a low level of mathematical representation (Hernawati, 2016; Hutagoal, 2013; Noto, Hartono, \& Sundawan, 2016).

To improve the students' mathematical representation, researchers chosen the Problem Based Learning (PBL) model. According to Delisle (Happy \& Widjajanti, 2014), PBL has several advantages such as students are encouraged to have the ability to solve problems in real life, students can build their knowledge through learning activities, learning focuses on problems, scientific activities occur students at workgroups, students are accustomed to using various sources of knowledge, and student difficulties can be overcome through discussion activities.

The PBL model presents contextual problems so that students need analytical skills to solve these problems (O'Brien, Wallach, \& Mash-Duncan, 2011). PBL is a bridge that connects theory and real-world application in a more environmentally friendly and familiar that enables students to acquire practical skills (Roh, 2003). According to previous research, it is known that PBL is effective in improving students' mathematical performance (Abdullah, Tarmizi, \& Abu, 2010). It also has a positive impact on students' in learning mathematics (Ahamad, Li, Shahrill, \& Prahmana, 2017; Botty, Shahrill, Jaidin, Li, \& Chong, 2016).

Due to the importance of mathematical representation in learning mathematics (especially in learning set theory), this study will analyze the effect of the PBL model on the students' mathematical representation. The purpose of this study is to determine the effect of the model PBL on the mathematical representation of Secondary School students in learning elementary set theory.

\section{METHOD}

This study is used posttest-only control group design. The design of the study can be drawn as follow:

$\begin{array}{lll}\mathrm{R} & \mathrm{X} & \mathrm{O}_{1} \\ \mathrm{R} & \mathrm{X} & \mathrm{O}_{2}\end{array}$

$\mathrm{R}$ : Randomly selected groups.

$\mathrm{O}_{1}$ : Posttest in the group that was given treatment.

$\mathrm{O}_{2}$ : Posttest in the group that was not given treatment.

$\mathrm{X}$ : The treatment given to the experimental class using the PBL model

The populations in this study were students of 7th-grade students at Secondary School in Palembang, South Sumatera, Indonesia. The samples were 27 students of 7.10 class as an experimental group (EG) and 27 students of 7.8 class as the control group (CG). 
Both classes are equal in mathematics performance. Data collected through tests, interviews, and documentation. The test is used to measure the students' mathematical representation that consists of 5 questions. The example of the problem can be seen in Figure 1.

Among a group of 45 residents shopping at Carrefour Palembang Square. It turned out that 20 people bought apples. 25 people bought mangoes. and 5 people bought them. How many people don't buy both?

Figure 1. The example of problem in postest

The result of the test is analyzed based on mathematical representation scoring (Table 1) developed by Cai, S.Jakabcsin, \& Lane (1996).

Table 1. The rubric scoring for mathematical representations

\begin{tabular}{clll}
\hline Score & \multicolumn{1}{c}{ Visual } & \multicolumn{1}{c}{ Symbolic } & \multicolumn{1}{c}{ Verbal } \\
\hline 0 & There is no answer, & \multicolumn{1}{c}{ even if there is only a lack of understanding of the concept so that } \\
the information provided does not & & \\
\hline 1 & $\begin{array}{l}\text { Only a few of the } \\
\text { drawings, diagrams } \\
\text { are correct. }\end{array}$ & $\begin{array}{l}\text { Only a few of the } \\
\text { mathematical models are } \\
\text { correct. }\end{array}$ & $\begin{array}{l}\text { Only a few of the explanations } \\
\text { are correct. }\end{array}$ \\
\hline 2 & $\begin{array}{l}\text { Draw diagrams, } \\
\text { pictures, but not } \\
\text { complete and } \\
\text { correct. }\end{array}$ & $\begin{array}{l}\text { Find the mathematical model } \\
\text { correctly, but wrong in getting } \\
\text { a solution. }\end{array}$ & $\begin{array}{l}\text { The mathematical explanation } \\
\text { makes sense but only partially } \\
\text { complete and correct. }\end{array}$ \\
\hline 3 & $\begin{array}{l}\text { Paint, diagram, } \\
\text { picture, in full, but } \\
\text { there are still a few } \\
\text { mistakes. }\end{array}$ & $\begin{array}{l}\text { Find the model correctly, then } \\
\text { do the calculation or get the } \\
\text { right solution but there are a } \\
\text { few mistakes writing symbols. }\end{array}$ & $\begin{array}{l}\text { The mathematical explanation } \\
\text { makes sense and is correct, } \\
\text { even though it is not arranged } \\
\text { logically or there are few } \\
\text { language errors. }\end{array}$ \\
\hline 4 & $\begin{array}{l}\text { Paint, diagram, } \\
\text { picture, completely } \\
\text { and correctly. }\end{array}$ & $\begin{array}{l}\text { Find the mathematical model } \\
\text { correctly, then do a calculation } \\
\text { or get a solution correctly and } \\
\text { completely. }\end{array}$ & $\begin{array}{l}\text { The mathematical explanation } \\
\text { makes sense and is clear and } \\
\text { logically arranged. }\end{array}$ \\
\hline
\end{tabular}

Data on students' mathematical representation then analyze with statistical inference. The prerequisite statistics testing then conducted. The interviews are held after the posttest. The interview results then analyzed descriptively.

\section{RESULTS AND DISCUSSION}

\subsection{Results}

This research was conducted in August 2019. The PBL model implemented in the experiment group (EG), consists of 27 students. Meanwhile, the control group (CG) got 
expository learning. The PBL model was design based on Lee \& Bae (Ahamad et al., 2017) as follow:

Step 1: Introduction, Understand the problem and Searching for information

Students are introduced to understand and analyze the set problem in the form of students' worksheets (see Figure 2). The worksheet also containing the use of signs and symbols in set theory.

Step 2: Construct and gather solution

Students are work collaboratively to find out the solution. Teachers controlling the students' work, and guiding the students who have troubles (see Figure 3a).

Step 3: Presentation and reflection

Students presented their findings in front of the class (see Figure 3b), the teacher checked their work and ask students to do some exercise.

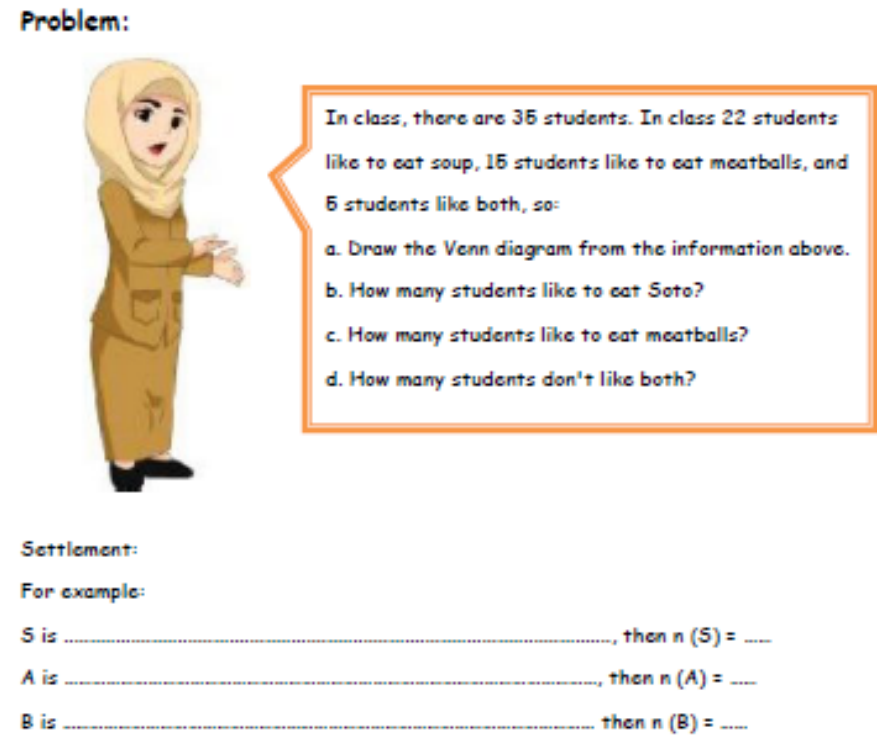

Figure 2. The example of students' PBL worksheet

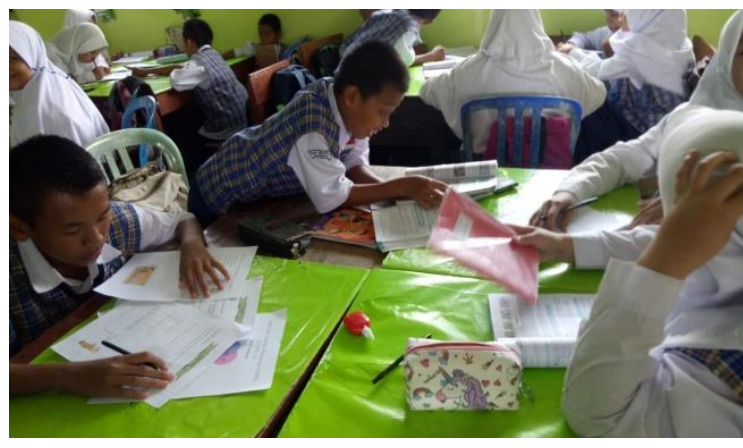

(a)

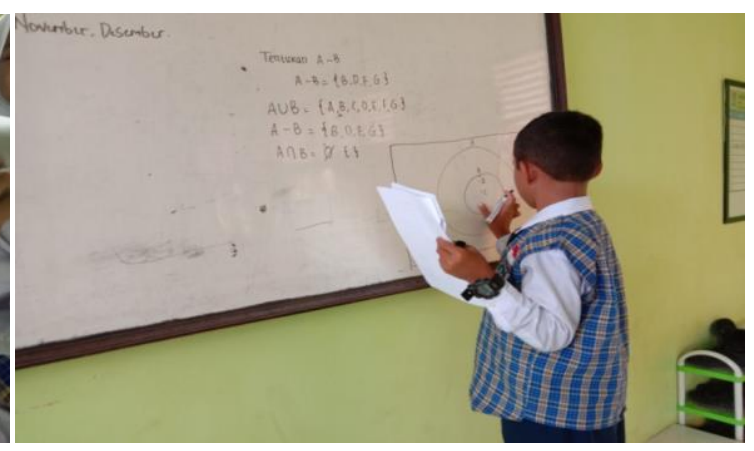

(b)

Figure 3. Students work collaboratively and presented their findings. 
The learning process was lasting in three meetings, and the posttest conducted in the fourth meeting. The statistical description of students' test results in mathematical representation (EG and CG) can be seen in Table 2.

Table 2. Descriptive statistics of students posttest

\begin{tabular}{ccc}
\hline & EG & CG \\
\hline $\bar{x}$ & 80.00 & 71.85 \\
$S$ & 7.34 & 7.23 \\
Max & 95 & 90 \\
Min & 65 & 60 \\
\hline
\end{tabular}

The result of the prerequisite test for hypothesis testing can be seen in Table 3 (normality test) and Table 4 (homogeneity test).

Table 3. The result of normality test

\begin{tabular}{ccccc}
\hline Groups & n & K-S & Sig & Conclusion \\
\hline EG & 27 & 0.710 & 0.694 & Normal \\
CG & 27 & 0.814 & 0.521 & Normal \\
\hline
\end{tabular}

Table 4. The result of homogeneity test

\begin{tabular}{ccccc}
\hline Groups & N & F & Sig & Conclusion \\
\hline EG and CG & 54 & 0.029 & 0.866 & Homogeneous \\
\hline
\end{tabular}

The hypothesis used in this research is the PBL model affects on students' mathematical representation. It means that there are differences mean between the two groups. Hypothesis testing is using the parametric statistics-t. The result of the t-test can be seen in Table 5.

Table 5. The result of the $t$-test

\begin{tabular}{ccccc}
\hline Groups & $\mathbf{n}$ & $\boldsymbol{t}$ & Sig & Conclusion \\
\hline EG & 27 & \multirow{2}{*}{4.111} & 0.000 & Different \\
CG & 27 & & & \\
\hline
\end{tabular}

There are three aspects of mathematical representation in this study. The posttest is consists of 5 questions. Questions number 1 is examined verbal representation, symbol representation in question number 2 and 3, and the visual representation in question number 4 and 5. Furthermore, the score of every aspect of mathematical representation can be seen in Table 6 .

Table 6. Students' mathematical representation of EG and CG

\begin{tabular}{lcc}
\hline \multicolumn{1}{c}{ Aspects of Mathematical Representation } & EG & CG \\
\hline $\begin{array}{l}\text { Verbal representation; the ability to describe the problem in the } \\
\text { form of written words. }\end{array}$ & 88.89 & 81.48 \\
$\begin{array}{l}\text { Symbol Representation; the ability to describe the problem in the } \\
\text { form of model / mathematical notation. }\end{array}$ & 70.37 & 57.40 \\
\hline
\end{tabular}




\begin{tabular}{lcc}
\hline \multicolumn{1}{c}{ Aspects of Mathematical Representation } & EG & CG \\
\hline $\begin{array}{l}\text { Visual representation; the ability to describe the problem in the } \\
\text { form of pictures / graphics. }\end{array}$ & 85.18 & 81.48 \\
\hline
\end{tabular}

Based on Table 6, it is known that the lowest score both in EG and CG was in the aspect of symbol representation. Interviews conducted to the chosen students to explore this finding. Some students stated that there are so many symbols in learning set theory, they difficult to remember and explain. They did not realize that the number of elements of set $A$ is $n(A)$ even though they know the number. They usually wrote the number and calculated it.

\subsection{Discussion}

Based on the result, it is known that PBL affects on students' mathematical representation in set theory topics. It is mean that PBL gives impact to students in learning mathematics. This finding is in a line with the previous studies (Abdullah et al., 2010; Ahamad et al., 2017; Botty et al., 2016;).

The first step of PBL is introducing students to the problem. Then students begin to understand the problem, searching the information to solve the problem. This step is to encourage students to discuss and sharing their idea to get the information (Ahamad et al., 2017). The proposed problem in PBL helps students to think critically (Abdullah et al., 2010; Padmavathy \& Mareesh, 2013).

After getting the information to solve the problem, students continue the activity to solve it. They working together, discussing, and struggling to complete their worksheet. This step is helping students in understanding the meaning of signs and symbols of set theory, and they also learn how to represent the set problem into a correct diagram Venn. This step is useful to improve their mathematical representation. Based on Tabel 6, known that the average score of symbol representation students in EG is higher than CG one. The example of students' posttest results can be seen in Figure 4.

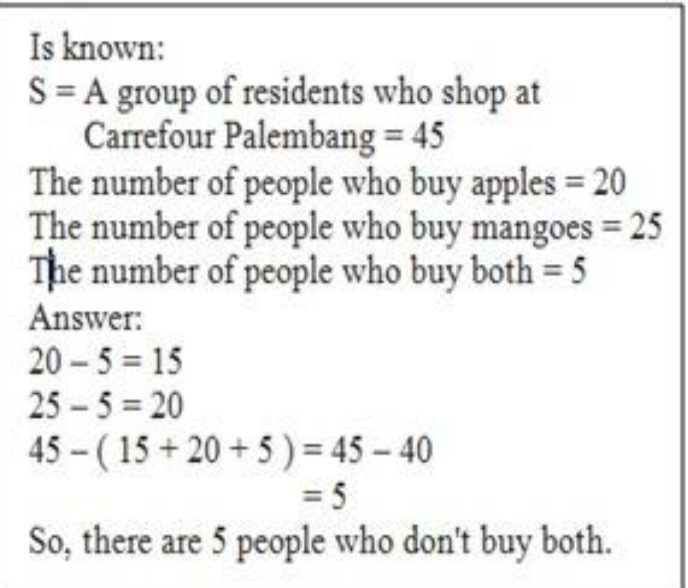

(a) Students' work at CG

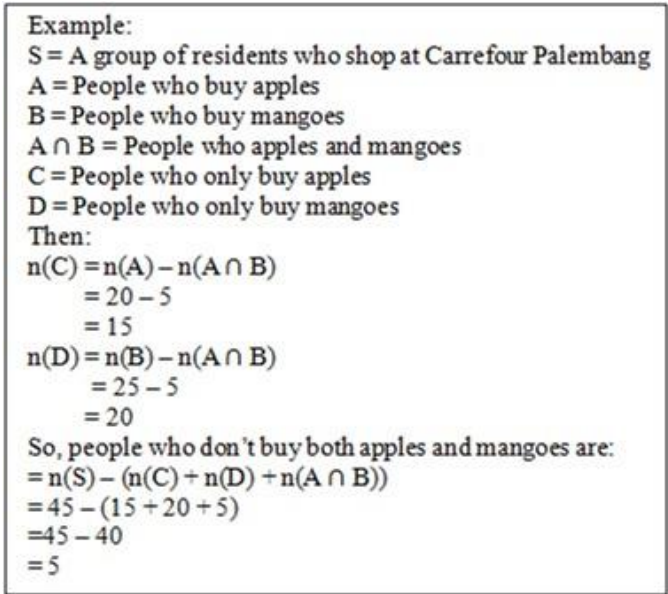

(b) Students' work at EG

Figure 4. Students' result for test of symbol representation

Based on Figure 4, both students can solve the given problem. However, students in EG show better performance in using signs and symbols. They can define the set from the problem. They make a correct notation for the element of the set, and the calculation is also correct. 


\section{CONCLUSION}

This study has shown that the PBL model affects on students' mathematical representation in learning the set theory topics. The t-test result reported that there is a difference mean between PBL and the expository model. After the PBL conducted, students in EG could write the problem into the notation of set. They make correct signs and symbols in set operation to solve the problem, they also have a good visual representation by forming the set into a correct diagram Venn. It can conclude that students who have a PBL model can develop their mathematical representation. This study is limited to elementary set theory topics, further study can expand for other topics. The symbol representation is still the hardest thing for students to learn. Suggestions for others study to analyze and improve this ability.

\section{REFERENCES}

Abdullah, N. I., Tarmizi, R. A., \& Abu, R. (2010). The effects of problem based learning on mathematics performance and affective attributes in learning statistics at form four secondary level. Procedia Social and Behavioral Science, 8, 370-376. https://doi.org/10.1016/j.sbspro.2010.12.052

Ahamad, S. N. S. H., Li, H. C., Shahrill, M., \& Prahmana, R. C. I. (2017). Implementation of problem-based learning in geometry lessons. In Journal of Physics: Conference Series, 943(1), 012008. https://doi.org/10.1088/1742-6596/943/1/012008

Andre, R. (2014). Axioms and Set Theory: A first course in Set Theory. Retrieved from http://www.math.uwaterloo.ca/ randre/1aaset_theory_140613.pdf

Bagni, G. T. (2006). Some cognitive difficulties related to the representations of two major concepts of set theory. Educational Studies in Mathematics, 62(3), 259-280. https://doi.org/10.1007/s10649-006-8545-3

Bolden, D., Barmby, P., Raine, S., \& Gardner, M. (2015). How young children view mathematical representations: a study using eye-tracking technology. Educational research, 57(1), 59-79. https://doi.org/10.1080/00131881.2014.983718

Botty, H. M. R. H., Shahrill, M., Jaidin, J. H., Li, H. C., \& Chong, M. S. F. (2016). The implementation of problem-based learning (PBL) in a year 9 mathematics classroom: a study in brunei darussalam. International Research in Education, 4(2), 34-47. https://doi.org/10.5296/ire.v4i2.9466

Cai, J., S.Jakabcsin, M., \& Lane, S. (1996). Assesing students' mathematical communication. Jurnal of Science and Mathematics, 96(5), 238-246. https://doi.org/10.1111/j.1949-8594.1996.tb10235.x

Dogan-Dunlap, H. (2006). Lack of set theory relevant prerequisite knowledge. International Journal of Mathematical Education in Science and Technology, 37(4), 401-410. https://doi.org/10.1080/00207390600594853

Happy, N., \& Widjajanti, D. B. (2014). Keefektifan PBL ditinjau dari kemampuan berpikir kritis dan kreatif matematis, serta self-esteem siswa SMP . Jurnal Riset Pendidikan Matematika, 1(1), 48-57. https://doi.org/10.21831/jrpm.v1i1.2663 
Hernawati, F. (2016). Pengembangan perangkat pembelajaran matematika dengan pendekatan PMRI berorientasi pada kemampuan representasi matematis. Jurnal Riset Pendidikan Matematika, 3(1), 34-44. https://doi.org/10.21831/jrpm.v3i1.9685

Hutagaol, K. (2013). Pembelajaran kontekstual untuk meningkatkan kemampuan representasi matematis siswa sekolah menengah pertama. Infinity Journal, 2(1), 8599.

Johar, R., \& Lubis, K. R. (2018). The analysis of students' mathematical representation errors in solving word problem related to graph. Jurnal Riset Pendidikan Matematika, 5(1), 96-107. https://doi.org/10.21831/jrpm.v5i1.17277

Noto, M. S., Hartono, W., \& Sundawan, D. (2016). Analysis of students mathematical representation and connection on analytical geometry subject. Infinity Journal, 5(2), 99-108. https://doi.org/10.22460/infinity.v5i2.p99-108

O'Brien, T. C., Wallach, C., \& Mash-Duncan, C. (2011). Problem-based learning in mathematics. The Mathematics Enthusiast, 8(1), 147-159.

Padmavathy, R. D., \& Mareesh, K. (2013). Effectiveness of problem based learning in mathematics. International Multidisciplinary e-Journal, 2(1), 45-51.

Razmjooei, A. (2013). Investigation of Some Cognitive Difficulties in Set Theory (Dissertation). Retrivied from http://urn.kb.se/resolve?urn=urn:nbn:se:su:diva91976

Roh, K. H. (2003). Problem-based learning in mathematics. Retrivied from https://files.eric.ed.gov/fulltext/ED482725.pdf

Zazkis, R., \& Gunn, C. (1997). Sets, subsets, and the empty set: students' constructions and mathematical conventions. Journal of Computers in Mathematics and Science Teaching, 16(1), 133-169. 